\title{
Proximity and the Pox: Pathologizing Infidelity in Marston's Dutch Courtesan
}

\begin{abstract}
Marston's Dutch Courtesan links the dangers of sexually transmitted infection and false religious doctrine, both spread by the Family of Love. The play finds dark comedy in the syphilis epidemic that urban sexual promiscuity perpetuated and in ridiculous religious heterodoxy. Both seem to thrive on infidelity. By making the tavern-owning Mulligrubs, the sex worker Franceschina, and her bawd Mary Faugh members of the Family of Love, Marston makes the corporeal dangers of illicit sex during an epidemic even more dangerous when its companion is the contagion of Familism, threatening to spread as efficiently as the syphilis ravaging early modern London.
\end{abstract}

When he first arrives on stage, Cocledemoy, the exuberant joker of John Marston's The Dutch Courtesan, trades affectionate insults with his paramour Mary Faugh. Their ribald banter first touches on the set of costly goblets they stole from Mulligrub the vintner, described in the previous scene. Cocledemoy demands their stolen goods from his 'worshipful, rotten, rough-bellied bawd', the 'bluetoothed patroness of natural wickedness' (1.2.3-5). ${ }^{1}$ Doubting his intentions, Mary Faugh at first refuses, prompting Cocledemoy to launch into a witty if somewhat elliptical and truncated - defence of his plans to profit from the theft. 'Restitution is Catholic', he says, 'and thou know'st we love -', but he leaves this thought hanging in the air, again insulting his lover as a 'worshipful clyster-pipe' and commenting on her profession $(8-9,12)$. Mary Faugh parries the insults of this 'foulest-mouthed, profane, railing brother', the first ironic phrase hinting at her sectarian identity, and then proudly professes her calling, 'a bawd that covers a multitude of sins', and her religious identity, 'one of the family of love ... none of the wicked that eat fish o'Fridays' (14-15, 18-20). In the space of about two dozen lines introducing this unscrupulous couple, Marston comically weaves together sex work, divergent religious identities, and a sexually transmitted

Andrew Fleck (ajfleck@utep.edu) is associate professor of English and director of the Liberal Arts Honors Program at the University of Texas. 
pathogen. As with many of the comedies set in Jacobean London, The Dutch Courtesan explores the commerce in sex and the risks of infection that result from sexual infidelity. Many London comedies of the period also explore infidelity of a religious kind, with overzealous or hypocritical characters turning from orthodox English Protestantism in favour of sectarian interests, and Marston's comedy takes up these issues as well, imagining a cell of members of the Family of Love, a disreputable sect popularly linked to sexual promiscuity, appropriate for a play centred on a Familist courtesan and her rotten bawd. In The Dutch Courtesan, however, Marston weaves together all of these concerns, creating a comedy in which infidelity - both unfaithfulness to the Church of England and unfaithfulness to monogamy as a result of dalliance with Familist sex workers - carries with it a potentially fatal infection of the body and the soul.

\section{Syphilis in the Stews}

A cloud of sexual contagion hovers over the London of Marston's Courtesan. In its opening scene, randy gallants comfort Mulligrub over the loss of gold vessels to Cocledemoy and his 'moveable chattel, his instrument of fornication, the bawd Mistress Mary Faugh' (1.1.18-20). As they bid one another good night, Tisefew's wistful valediction, 'Sound wench, soft sleep, and sanguine dreams' (63-4, my emphasis), casually acknowledges how rarely his friends sleep with an uninfected woman. Cocledemoy, who makes similar gibes when departing from gallants, hopes Freevill will have 'Grace and mercy' to 'keep your syringe straight' (1.2.82), a medical joke about the risk to his friend's member and its potency by keeping company with Franceschina, a sex worker. Later, as he tricks the young apprentice barber Holofernes Reinscure into lending him the tools of his trade, Cocledemoy offers a variety of knowing double entendres about a barber's main duty in taverns and brothels: the treatment of syphilis. ${ }^{2}$ Preparing to 'shave' Mulligrub of more of the vintner's money, he makes several wisecracks, including one about the sexual contagion of the place, as Freevill leaves the courtesan Franceschina's rooms ('Does your worship want a barber surgeon?' [2.1.170]). Cocledemoy jokes frequently about syphilis, sometimes caustically, with the comedy's women, as we have seen. He calls Mary Faugh his 'fine rattling phlegmy cough o'the lungs and cold with a pox ... my precious pand'ress, supportress of barber surgeons and enhauntress of lotium and diet drink' (1.2.22-6). As his remarks indicate, the threat of disease goes both ways, with Crispinella lamenting that healthy young women must accept social kissing, even 'if a nobleman or knight with one lock visit us, though his unclean, goose-turd-green teeth ha'the palsy ... and his loose beard drops into 
our bosom, yet we must kiss him with a cur'sy' (3.1.20-4). A suitor losing his facial hair, a symptom of syphilis, must still be kissed for courtesy's sake, even if it endangers a healthy young woman. Mary Faugh's recollection that it was she 'Who paid the apothecary' (2.2.30) suggests that Franceschina herself, as a result of her profession, has experienced sexual infections. Cocledemoy's ironic praise of Mary Faugh's profession, setting it 'above the twelve companies' because she sells 'the best ware ... virginity, modesty and such rare gems ... by wholesale' — referring to the sale of the prostitute's holes - returns to the cramped conditions of early modern London, where bawds must live and die well because 'they live in Clerkenwell and die in Bridewell' (1.2.32, 38-42, 58-9), one a parish notorious for its brothels, and the other a prison for women, many of them syphilitic prostitutes. Nearly everyone in Marston's cramped London worries about contracting syphilis.

The syphilis that swept through early modern London seems to have been more virulent and thus more terrifying than we may now realize. In England, its keenest observer was the surgeon William Clowes, whose A Short and Profitable Treatise Touching the Cure of the Disease Called (Morbus Gallicus) by Unctions appeared in three editions at the end of the sixteenth century. Clowes describes the terrifying symptoms of syphilis, which 'corrupteth the bloud, and poysoneth the whole body $\&$ bredeth in the partes thereof paynes, aches, ulcers, nod[e]s, and foule skabbs. ${ }^{3} \mathrm{He}$ does not focus on the hair loss or the damage to the nose later commentators mention. For Clowes, among the most obvious signs that an individual has contracted syphilis, or the French disease, are the disfiguring sores and 'venemous pustules with a certayne hardnes sticking out in the head, forehead, browes, face, or beard, and in other partes of the bodye, especially about the secret partes, or lowest part of the bellye, or in the corners of the lippes, and that especially in infantes. ${ }^{4}$ This last detail about syphilis in infants points to the broad threat of the early modern disease. It could pass from infected nursemaids to infants at the breast. Physicians thought this disease could also be caught 'by sitting on the same stoole of easement which some infected persons frequenteth' or by sharing a cup with an infected person, wearing their cast-off clothing, or lying in sheets in which an infected person had slept. ${ }^{5}$ Although he pities infants and others who innocently became infected, he has the greatest contempt for the 'filthy lyfe of many lewd and idell persons, both men, and women, about the citye of London', especially for those 'filthy creatures' who undergo treatment for the malady, 'the best kinde of cure used', and then 'reneweth' syphilis by returning to the source of disease. ${ }^{6}$ The 'relentless' Clowes, as William Kerwin observes, combined moral opprobrium with a clear-eyed, empirical observation. ${ }^{7}$ Early modern 
syphilis in the popular imagination might have seemed as contagious as the more lethal bubonic plague found in the densely populated parishes of early modern London.

Women bore the popular and medical blame for the disease. Men's sexual violence may have spread the infection across Europe, but women were treated as the source of the outbreak. Peter Lowe, another London surgeon, recounts how soldiers carried the malady from one campaign to another. When he turns to fundamental questions about the transmission of the disease in individuals, however, he declares that 'this maladie proceedeth cheefely from the act of Venus, whe[n] men haue to doe with women polluted with that infection'. ${ }^{8}$ The disease finds an amenable host in a woman's 'Matrix, whereof for the most part, proceedeth the originall of this disease.'? Thomas Nashe, in Christ's Tears over Jerusalem, inveighs against the social sins he observes in London, misogynistically warning women not to make 'your bodies stincking dungeons for diseases to dwell in'. ${ }^{10}$ Ascribing the source of pollution to women, these writers turn the city's brothels, in which women typically entertain a male clientele, into the most threatening source of this relatively new sexual affliction.

Early modern urban comedies make much of the connection between the relative anonymity of urban life, the attraction of the stews, and women's role in spreading the disease. In Thomas Dekker and Thomas Middleton's The Honest Whore (1604), for instance, Hippolito confronts the courtesan Bellafront with the variety of dangers she poses. He returns again and again to the risk to her own health and the health of her clients. Hippolito declares, for example, that 'a toad is happier then a whore' since the loathsome amphibian 'with one poison swells, with thousands more / The other stocks her veins' (2.1.360-2, my emphasis). ${ }^{11}$ The sexually transmitted diseases within the prostitute's body represent an epidemic menace. Hippolito recalls examples of 'As many by one harlot, maym'd and dismembered, / As would ha' stuft an Hospitall' (332-3). From this hyperbolic description of Bellafront's threat to men's health, Hippolito descends into popular, comic stereotypes, asserting that her international clientele must surely include a syphilitic Frenchman who

sticks to you faith: gives you your diet,

Brings you acquainted, first with monsier Doctor,

And then you know what followes.

The combination of moral disapproval and physical disgust in Hippolito's invective prompts Bellafront to abandon her profession, frustrating her many clients. In response, she urges them to heap calumny on her for her former life and to turn 
away from their own incontinence. 'Let me perswade you to forsake all Harlots, / Worse then the deadliest poysons' (3.3.49-50), she declares, and further asks

What shallow sonne and heire then, foolish gallant,

Would waste all of his inheritance, to purchase
A filthy, loathd disease.
$(60-2)^{13}$

While gallants may spend some of their wealth in order to enjoy a courtesan's favour, providing her with temporary gain, in the long term their offerings cannot help the courtesan when her body fails; moreover, the foolish gallants waste their remaining wealth acquiring the malady that will leave them financially, physically, and morally destitute.

Many other plays in the years before The Dutch Courtesan testify to the fear that female sex workers fostered the syphilis epidemic. Some familiar scenes from Shakespeare remind us of the prevalence of this discourse. Falstaff and his friends associate with bawds and prostitutes in Quickly's tavern. In Henry IV Part Two (1598), as figurative illness saps the nation's health, Falstaff and the prostitute Doll Tearsheet trade barbs about her role in 'mak[ing] the diseases' her clients take from her (2.4.41). ${ }^{14}$ At the end of Henry $V$ (1599), Pistol will report that, while he has been away in the wars, Doll has died ' $i$ ' th' spital of a malady of France' (5.1.73). The oppressive atmosphere of Measure for Measure (1604), in which sexual licentiousness and widespread sexual infection go hand in hand, is one in which 'sexual desire is intrinsically, disgracefully errant' to authority and when 'subject to public punishment, it becomes by reflex something to hide'.15 The bawd, Mistress Overdone, arrives on stage prefaced with a series of punning references to syphilis. ${ }^{16}$ Lucio announces the arrival of 'Madame Mitigation' by lamenting that he has 'purchased as many diseases under her roof as come to ... three thousand dolors a year ... [and] A French crown more' (1.2.41-8). Having earlier needled the First Gentleman with claims that he is losing his hair due to the effects of syphilis, Lucio derides him with a promise to toast 'thy health, but, whilst I live, forget to drink after thee' (36) lest he catch the French disease by sharing a cup. The gibes about additional symptoms of syphilis, such as hollow bones and sciatica, that they trade through the rest of the scene make light of the syphilis ravaging the city (superficially, Vienna, though recognizably London) and prompting Angelo's crackdown on sexual vices in the capital.

Freevill, the compromised protagonist of The Dutch Courtesan, expresses some of the same fears of lurking sexual contagion in the urban squalor that figures elsewhere in the play and in other contemporary city comedies. This gallant, who chooses between 'the love of a courtesan and a wife' (1-2), according to the 
comedy's 'Fabulae argumentum', witnesses the murderous wrath of his spurned lover and the remarkable fidelity of his betrothed Beatrice, learning to value their loves accordingly. Having enjoyed London as a young libertine, he now plans to wed, seems prepared to abandon his wandering ways, and expects sexual fidelity from his bride-to-be. Of course, having participated in the sybaritic ways of London gallants, Freevill knows that some dangers to marital bliss lurk in London's shadows. ${ }^{17}$ As the gallants disperse after Tisefew's wish that they find sound wenches, Malheureux sticks close to Freevill, whom he suspects will be heading toward 'some common house of lascivious entertainment' (1.1.70), prompting a debate about the merits and vices of prostitution. Taunting his puritanical friend, the sardonic Freevill claims to think of brothels as 'necessary buildings' that serve a social purpose (71). ${ }^{18} \mathrm{He}$ once frequented them, rather than seducing citizens' wives, and now he hopes they will serve a similar purpose and preserve the health of the bed he will enjoy when he weds. Malheureux, on the other hand, whose 'cold blood' and 'professed abstinence' $(1.2 .86,124)$ eventually melt in the face of sudden desire, initially makes the case against prostitutes and the maladies they spread. Echoing the reformed prostitute Bellafront, Malheureux warns Freevill not to 'grow wild in loose lasciviousness / ... to expose your health and strength ... / to the stale use, / The common bosom, of a money-creature' (1.1.98-104). He objects to an immoral and degrading commerce, but also worries about the risk to his friend's health.

Although Freevill defends sex work, he acknowledges some of its risks. In responding to the moralizing disgust of Malheureux, Freevill initially makes the case that enterprising prostitutes deserve sympathy before he eventually mocks their dire straits, arriving at one of Malheureux's points from a different angle: 'employ your money upon women, and a thousand to nothing, some one of them will bestow that', usually glossed as syphilis, 'on you which shall stick by you as long as you live' (128-31, my emphasis). Freevill may dismiss the sinful aspect of sex work, but he acknowledges and jokes about the syphilis spreading through the trade. Making his point almost more explicit, he goes on to say 'give them the French crown', the money they require for services, 'they'll give you the French -', meaning pox or syphilis (134-5). The fashionable gallant initially prefers not to 'call things by their right names', using a variety of euphemisms for Franceschina and noting that if a syphilitic gallant is 'pocky' the better nomenclature is to 'say he has the court scab' (1.2.112, 115-16). Although Garrett Sullivan Jr notes the uncanny overlap of prostitution in the varieties of early modern women's labour, the commercial element of sex work is not this essay's focus; nevertheless, as Jonathan Gil Harris notes, syphilis and the 'compromise formation' of the emerging 
mercantilist economy in early modern England shared a 'bivalent' etiology, seeming at once to emerge from within and to affect the individual from without. ${ }^{19}$ By the end of Marston's comedy, Freevill comes to understand the play's supposed purpose, the 'difference betwixt the love of a courtesan and a wife', having witnessed Franceschina's wicked plot to kill him and frame her new innamorato Malheureux. In his final soliloquy, the apparently reformed Freevill now asks in disbelief what man 'Would leave the modest pleasures of a lawful bed' for 'the unhealthful loins of common loves' whose 'use makes weak, whose company doth shame, / Whose bed doth beggar, issue doth defame' (5.1.78, 83-4). ${ }^{20}$ As these lines suggest, the risk to the body and the risk to the soul associated with visiting prostitutes can be hard to untangle.

\section{Morality and Mortality in London's Brothels}

As shocking as Freevill's joke about the 'necessary buildings' on the city's margins might be, the notion that tolerating their existence, even if immoral, might be pragmatic, includes a calculation about social control of contagion. ${ }^{21}$ Regulated brothels had operated in Southwark from the medieval period through the reign of Henry VIII. John Stow records that adjacent to the Bear Gardens 'was sometime the Bordello, or Stewes, a place so called of certain stew-houses privileged there, for the repair of incontinent men to the like women'. ${ }^{22}$ These brothels, in the same neighborhood where the Elizabethan amphitheatres now stood, 'had signs on their fronts, towards the Thames ... as a Boar's head, the Cross keys, the Gun, the Castle' and so on. ${ }^{23}$ The women who worked in these establishments, Stow notes, 'were forbidden the rites of the church' and were 'excluded from Christian burial'. 24 At mid-century, 'this row of stews in Southwarke was put down by the king's commandment' and 'the inhabitants of the same to keep good and honest rule as in other places of this realm. ${ }^{25}$ That resolve lasted only briefly. By the time of Marston's The Dutch Courtesan, brothels had again arisen on the crowded south bank of the Thames, much to the frustration of moralists, physicians, and (at least superficially) satirists.

As syphilis swept through London, accelerated by the early modern sex trade practiced in necessary buildings like Franceschina's and Mary Faugh's, its ravages did not inspire the appropriate action from civic authorities, prompting satirists to criticize the weak response. The Bellman of London, the narrator of Thomas Dekker's Lantern and Candlelight (1608), laments the city's diseased, 'pockily dry' suburbs with their proliferation of alehouses. ${ }^{26}$ Adding a figurative register to the literal spread of disease associated with prostitution, Dekker's Bellman laments 
that 'the plague a whore-house lays upon a city is worse, yet is laughed at; if not laughed at, yet not looked into; or if looked into, winked at'. That malady, the Bellman shows, is not simply the syphilis that spreads out through the open 'Hellgates' of the Cross-Keys or other brothels, but the moral decay that accompanies prostitution. A 'strumpet', the Bellman goes on, is 'the cockatrice that hatcheth all these eggs of evils'. Recombining the physical and the spiritual, the Bellman concludes by arguing that when 'the Devil takes the anatomy of all damnable sins, he looks only upon her body'. ${ }^{27}$ With Middleton, his collaborator on The Honest Whore, Dekker penned another grim account of London's competing epidemic, bubonic plague, 'This proud Inuader', in News from Gravesend (1604). ${ }^{28}$ Pointing to the many vices in its urban sprawl, the narrator suggests that if only London would 'Cease vexing heauen', it could 'cease to die. ${ }^{29}$ The sexual infidelities staged in London comedies may imagine a jealous husband, whose 'wyfe has played the womans part / And lyen with Death', taking satisfaction in the fact that her paramour contracts a sexually transmitted infection and dies 'of all forsaken', while elsewhere panderers and strumpets overconfidently believe 'their deaths come o'er from France' and its pox, making them immune to the plague. ${ }^{30}$

Attributing syphilis to something more than the promiscuous sexual contact that helped it spread, writers of all sorts made moral judgments about the disease. In Syphilis, sive Morbus Gallicus, Giralomo Fracastoro, the first European physician to offer a comprehensive view of the malady, had associated syphilis with divine punishment for blasphemy. In this remarkable georgic, the physician imagines the origin of the disease in divine displeasure when a shepherd named Syphilus apotheosizes Alcithoos, his king, and raises an altar to him. When the king learns that Syphilus has created a new religion to worship him, 'he ordered that no god be honored on earth or be held higher than himself' (3.319-20). ${ }^{31}$ For this heresy, the gods punish the king and his high priest. An 'unknown pollution arose', striking Syphilus first, with 'disfiguring sores throughout his body' and leaving him sleepless and his body 'convulsed', in retribution for his blasphemy (329-31). The king suffered next and the new malady spread throughout his territory. For his role in angering the gods, the infamous Syphilus metonymically names the disease. Syphilis, then, beyond its association with immoral sexual conduct, might suggest for some at least a connection to heresy.

The illicit sexuality observed in London prompted others with a more vested interest in the problem to speak out about the immorality, as well as the literal diseases, running rampant in the stews. Harris notes that earlier in the century, John Colet had attributed the rise of syphilis to an imbalance of humours associated with indulgence of the immoral and 'inordinate misuse of the flesh'. ${ }^{32}$ 
Clowes would draw on his medical experience to articulate a disappointment akin to Dekker's Bellman, declaring that 'except the people of the land doe speedily repe[n]t their most ungodlylife, and leave this odious sinne, it cannot be but the whole land will shortly be poysoned with this most noysome sickness'. ${ }^{33}$ In a more straightforward piece of invective, Nashe would enumerate the sins of London in Christ's Tears over Jerusalem (1593). There, he describes the suburbs' brazen prostitutes in nauseating detail, recalling 'The speech-shunning sores and sight-ircking botches of theyr vnsatiate intemperence. ${ }^{34}$ These sites of sin may no longer have the royal patronage Stow recalls, but the magistrates' tolerance for vice earns some of the satirist's scorn as well. Like Dekker, this satirist asks how 'so many brothel-houses of salary sensuality $\&$ sixe-penny whoredome (the next doore to the Magistrates)' can operate openly and be 'maintained, if brybes dyd not bestirre them?'35 As Alexandra Walsham notes, in early modern England, where individuals of different confessional backgrounds lived cheek by jowl with one another, the insidious link between disease and deviance remained close to the surface of contemporary assumptions, ever ready to inject an element of distrust into inter-confessional relations. ${ }^{36}$ Although some in early modern Europe thought they could detect unsound doctrine in unsound bodies, the bodily and spiritual degeneration in The Dutch Courtesan does not align so neatly along confessional lines. ${ }^{37}$ Regardless, the shared confessional trope that linked heterodox belief with sexual incontinence crops up in Marston's comedy.

\section{Contagious Sects and Unfaithfulness in London Comedy}

Marston goes a step further than his contemporaries in the use to which he puts comedy about prostitution, syphilis, immorality, and unorthodox religious views. In Thomas Nashe's Pierce Penniless, the narrator, Pierce, laments the prevalence of sexual infections in 'Ladie London' who has 'more diseases than Newgate', and observes that in Westminster 'not a Wench sooner creepes out of the shell, but she is of the Religion'. ${ }^{38}$ Pierce's ironic phrase 'of the Religion' comes to mean one participating in the sex trade, thereby trafficking in sexually transmitted infections. A few years later in Henry IV, Part Two, Falstaff (sometimes himself linked to the hypocritical linguistic tics of early modern puritans) turns to Doll Tearsheet who is in the dumps - or mulligrubs - in Quickly's tavern, and declares that she and 'all her sect' have become 'sick', prompting Doll to reply, 'A pox damn you' (2.4.33-5). ${ }^{39}$ For Falstaff, prostitutes jokingly represent a diseased 'sect', and he draws on figures not simply from moralizing discourse but from the arsenal of theological critiques directed at those who do not conform to the church's 
teachings. In The Dutch Courtesan, Marston combines a satirical moral lens with a satirical treatment of venereal disease, taking the extra step of moving from a general sense of immorality in the brothel to a specific kind of unsavoury religious expression: the sect known as the Family of Love. This theologically quiet but theatrically sexy sect had taken root in England more than half a century earlier. ${ }^{40}$ As Marston wrote his comedy, most faithful English Protestants abhorred the Familists' infidelity to the Church of England and worried that this secretive, licentious sect was furtively infecting others with its diseased teachings.

The language of contagion has demarcated confessional communities for millennia, but the spread of syphilis, a disease typically communicated through extramarital sexual contact Christians deemed immoral, gave even greater urgency to these prophylactic tropes. The idea that heretics' ideas could prove viral satisfied polemicists of all stripes. Some wondered whether 'unclean members i'the congregation' (3.3.3) - to quote Mistress Purge in Barry's Family of Love (1608) should be expelled from the community. ${ }^{41}$ An English translation of Jean-François Salvard's Harmonia confessionum fidei orthodoxarum et reformatarum ecclesiarum (1586), for instance, informed English readers that the reformed Swiss community excommunicated those with 'strange, and wicked opinions', and that obstinate members should be 'bridled by the Magistrate, lest by their contagion they infect the flocke of Christ. ${ }^{42}$ The Hebrew Bible and the New Testament offered precedents for shunning heretics, who might spread their impious disease. The puritan divine William Attersoll, for instance, produced a lengthy commentary arguing that Moses, and after him Christ, had shown that sinners 'should not be admitted to the fellowship ... lest they defile them and corrupt them through their contagion', with 'Sinne therefore being infectious, the sinner is not to be tollerated in the assembly of the righteous. ${ }^{43}$ John Paget, an English minister resident in Amsterdam, defended his critiques of the English Brownists, intended as 'wholesome and necessary warnings to keep every Christian man from such a contagious and polluted communion'. ${ }^{44}$ The notion that profane ideas might spread like a disease had wide application in the period.

These threads of concern about the contagion of dangerously heretical ideas reach a culmination in the figure of Revelation's Whore of Babylon. The whore, 'araied in purple \& skarlat' had 'a cup of golde in her hand, ful of abomination, and filthines of her fornication'. 45 This abominable, lecherous woman - who might stand behind Marston's promiscuous courtesan - spreads her heresy to the unsuspecting and she figures prominently in Protestant polemic. ${ }^{46} \mathrm{John}$ Bale, for instance, cannot get enough of the Whore of Babylon. In addition to her appearance throughout the Image of Both Churches (1544), he turns to the figure 
of the pampered Whore adored by hypocrites when he attacks the conservative episcopacy of the Henrician church. Condemning their inadequate reformation and refusal to rebuke the papal antichrist, Bale sarcastically commends their 'unlerned legerdemaynes' that will earn 'double vpon that Romysche whore your malygnau[n]t madame / the mother of all fylthynesse / Idolatrye / ... lechere / sodometrye' and so on. ${ }^{47}$ As zealous communities debated separating themselves from their national church, they could consult Philippe de Mornay for justification. He argued that 'lyuinge in the middest of a wicked and peruerse Nation', even a nominally Protestant one, made a godly person risk 'to bee so infected with the contagion of Babylon' from long exposure to others' vices. ${ }^{48}$ Dekker would bring these tropes to the stage in The Whore of Babylon (1605), his allegorical attack on the church of Rome and its threats to Protestant England. ${ }^{49}$ The Whore's pollution, figuring spiritual seduction through the contamination received in sexual contact, had great potency.

When Marston linked the polluted sex workers and other promiscuous figures of his play to the Family of Love, he contributed to an English tradition of using the language of contagion to rebuke the nebulous Dutch sect that had spread invisibly in England for decades. After a period of quiet, Familism experienced a new outbreak at the start of King James's reign, just as Marston was writing The Dutch Courtesan and Lording Barry was writing his satire of the sect, The Family of Love. The king's revision of Basilikon Doron to fit the circumstances in his new kingdom may have prompted the renewed interest in this mystical sect at the start of his reign. ${ }^{50}$ Familists appear in about a dozen London comedies early in King James's reign and a piece of polemic, A Supplication of the Family of Love, appeared in 1606. In the heated dispute at the time of their first Elizabethan prominence, the mystical movement's critics had warned of the infectious danger of harbouring this sect in England. John Knewstub complained, 'the Church of God in euery age hath suffred at the hands of straungers \& open enemies ... but yet nothing so grieuous, as that hurte which she hath fro[m] time to time had at home, by some who have long layen in her owne bosome.. ${ }^{51}$ Putting aside Familists' amorphous theology, the Jacobean theatre traded in a comically exaggerated version of the Family of Love. This mystical sect of Nicodemites was popularly believed to be so devoted to communal principles that they held their wives in common. In other words, one of the stereotypes of the Family of Love was that they were sexually promiscuous, a particularly risky practice given the prominence of syphilis in non-monogamous settings.

The promiscuous, heretical sex worker and bawd at the heart of The Dutch Courtesan makes that aspect of the popular notion of Familism conveniently 
overdetermined. Franceschina seems out of place, a strange hybrid, in the play, since her Italian sophistication (and fury, for that matter) jars with her guttural stage Dutch. ${ }^{52}$ Moreover, when she swears, she uses terms associated with syphilis. Enraged that Freevill plans to abandon her, she refuses Mary Faugh's mollification, declaring 'Grand grincome on your sentences' (2.2.7), and curses her faithless lover Freevill with 'de hot Neapolitan poc rot him' (52-3). Her diseaseinflected curses even combine blasphemy and syphilis, as when she gets frustrated with Cocledemoy's teasing and chases him off stage shouting 'God's sacrament! Pox!' (4.3.10). The most sexually available figure in the comedy, a hedonistic sex worker who carries corporeal and spiritual infection, drives home Marston's figuration of the dangers of the brothel. Malheueux may wilt when confronted with Franceschina's attractions, but in abandoning his moral principles to pursue her, he risks not simply hypocrisy, but also physical and spiritual infection.

Franceschina is not the only professed member of the Family of Love in the play. The Mulligrubs are Familists and Mistress Mulligrub — often 'a-gadding' (3.4.101) as heterodox early modern women were prone to doing - pauses over fine points of theology that her simply sectarian husband does not. Besides the more well-known example of her worries about whether their wines are Protestant, one of Mistress Mulligrub's other significant monologues involves sexual innuendo that reinforces her sexual availability in commercial and religious professions. ${ }^{53}$ Adopting the archaic language associated with sects, she worries about her customers' love of tobacco, which 'one of our elders assured me ... was not used in the congregation of the family of love' (4-6). Her train of thought leads her to use an unfamiliar word, 'methodically', and then to try to remember where she learned it, recalling at last that another Familist: 'Sir Aminadab Ruth bade me kiss him methodically' (10-11). Alluding to the sexual freedom supposed to form part of Familist gatherings, she recalls a moment of marital infidelity that occurred in the context of her infidelity to Protestant English orthodoxy. Inverting the figure of Pierce Penniless's naive young woman who indulges in promiscuity and quickly becomes one 'of the Religion', Mistress Mulligrub is 'of the Religion', and therefore promiscuous. When Mistress Mulligrub remarks that customers bring her a 'piece of flesh' (3.3.26) — with its sexual connotations she pushes to the theatrical extreme the concern that London tradesmen's wives displayed not only their wares but themselves in order to improve their husbands' custom. ${ }^{54}$ As Cocledemoy in his sergeant's disguise makes lewd offers to Mistress Mulligrub while leading her husband to execution, her seductive reply — 'I have a piece of mutton and a featherbed for you at all times' - makes her openness to infidelity even more apparent (5.3.100-2). Her education in carnal pleasure from 
an elder in her sect relies on the notion of Familist promiscuity even as it links this heterodox group with the play's illicit sexuality. Secretly maintaining unorthodox religious views and unorthodox erotic energies, Mistress Mulligrub shows that in the early modern imagination, women need not be literal prostitutes to spread heretical contagion. Her clients and lovers may include others of the sect, but not all of the knights and courtiers who patronize the Mulligrub tavern are Familists and her potential coupling with them would spread her contagion beyond the sect's bounds.

Finally, the most decrepit character of the comedy, the 'rattling phlegmy cough o'the lungs and cold with a pox' bawd, Mary Faugh, is also a pragmatically promiscuous Familist. She is, as Cocledemoy asserts, an 'ungodly fire that burnt Diana's temple' (1.2.11), an affectionate insult that links the fire of syphilis, her impious beliefs, and her threat to chaste conventionality. Like one of Nashe's cynical 'Merchants of maiden-head' in Christ's Tears over Jerusalem, ${ }^{55}$ she has arranged Franceschina's numerous previous liaisons with a Spaniard, an Italian, an Irish lord, and a Dutch merchant (2.2.16-19), not to mention the 'honest flatcaps, wealthy flat-caps, that pay for their pleasure the best of any men in Europe, nay, which is more, in London' (35-7). She facilitates an urban and international promiscuity as she sells Franceschina's holes wholesale. Her harsh exchange with Franceschina, who calls Faugh a 'reprobate woman' - not simply immoral, but spiritually damned - and worries what she herself will do, now that for twopence 'Mine body must turn Turk' or become apostate (45-7), connects the promiscuity of their immoral sex trade and the contagion of their heretical beliefs. The spiritually depraved Mary Faugh facilitates the circulation of diseases of the body and the soul. As she exits to find chairs for Freevill and Malheureux, Freevill alludes to the pestilence that lingers in this necessary, Familist building. He asks the visibly symptomatic bawd 'How far off dwells the house-surgeon' who can cure Malheureux of a toothache if he is not busy treating her other employees or clients for syphilis. To this provocation, Mary Faugh defensively responds, 'You are a profane fellow, i'fait. I little thought to hear such ungodly terms come from your lips' (79-81). Like the other fallen women of her sect, she understands her practices as pious and others' practices as profane. The humour of this line an unfaithful Familist who facilitates prostitution condemning someone else for being immoral - brings together Marston's unique combination of not simply immorality and disease, but the dangerous sectarian vector of disease, a risk both to the body and soul as well as to orthodoxy, in The Dutch Courtesan.

Marston, then, uses Courtesan's amoral Familists to heighten the concerns of early modern London comedy's depiction of the brothel as a menacing location. 
Brothels and their residents may entice immoral men to risk their health in coupling with carriers of a disease that might 'stick by [them] as long as [they] live' (1.1.128-31). Those who submit to the brothel's appeal may evince their immorality and 'the soul's eternity' in committing a sin with their courtesan (96). Unlike those of his fellow playwrights who treat the comical appeal of the brothel as a source of disease or a source of immorality, Marston adds a new layer of spiritual danger by making the pestilential brothel a source of heretical ideas. Nashe might have predicted Marston's decision when he inveighed against the brothels overlooked by the magistrates in Christ's Tears over Jerusalem. Notorious denizens of the stews may avoid the services of their parish church, lest the pious 'wonde[r] and how[l] at' them, as moralists had advised, but if the magistrates do finally haul them to church courts for failing to participate, the sex worker typically claims 'scrupulousity of conscience, and that they refraine only for religion. So if they be imprisoned or carried to Bridewel for their baudrie, they giue out they suffer for the Church'. ${ }^{56}$ The idea that a dangerous Familist prostitute, her pocky Familist bawd, and the lascivious Familists of the Mulligrub tavern might be eschewing the orthodox practices of London's churches due to their scrupulous consciences and suffering throughout the play, not for their diseased practices but for their diseased church, must have made Marston and his audiences laugh. 


\section{Notes}

1 John Marston, The Dutch Courtesan, ed. Karen Britland (London, 2018). All further references to the play are to this edition.

2 In addition to reading Cocledemoy's dissembling as a reference to contemporary concerns about quack medical practitioners in early modern London, Eleanor Decamp notes that one aspect of Cocledemoy's role here is to remind the audience of the syphilitic threat emanating from the bawdy house. See Civic and Medical Worlds in Early Modern England (Basingstoke, 2016), 72, https://doi.org/10.1057/9781137471567. William Kerwin offers a much more nuanced analysis of the role of surgeons and barbers in early modern London, noting that 'the rise of the pox' created a more pressing need for their services. Beyond the Body: The Boundaries of Medicine and English Renaissance Drama (Amherst, 2005), 98.

3 William Clowes, A Short and Profitable Treatise Touching the Cure of the Disease Called (Morbus Gallicus) by Unctions (London, 1579; sтc: 5447), B6r-v.

4 Ibid, B6v.

5 Ibid, B5r. Gail Kern Paster alerts us to the early modern attitude toward the porous body and to female shame, particularly in connection with excremental functions, in The Body Embarrassed: Drama and the Disciplines of Shame in Early Modern England (Ithaca, 1993).

6 Clowes, A Short and Profitable Treatise, B1r.

7 Kerwin, Beyond the Body, 105.

8 Peter Lowe, An Easie, Certaine, and Perfect Method, to Cure and Preuent the Spanish Sicknes (London, 1596; sTC: 16872), B2r.

9 Ibid, B1v. Eleanor Hubbard discusses women who weighed the income to be made in the sex trade against the risk of syphilis. City Women: Money, Sex, and the Social Order in Early Modern London (Oxford, 2012), 109, https://doi.org/10.1093/acprof:o so/9780199609345.001.0001. Her discussion of women who illicitly offered medical assistance to those suffering from syphilis shows that bitterness about the disease was often directed at women (217).

10 Thomas Nashe, Christs Teares over Iervsalem, in Works, ed. Ronald McKerrow, 5 vols (Oxford, 1958), 2.154. Further references are to McKerrow's edition.

11 Thomas Dekker and Thomas Middleton, The Honest Whore, Part 1, in The Dramatic Works of Thomas Dekker, ed. Fredson Bowers, 4 vols (Cambridge, 1955), vol. 2. Sarah Scott reminds us that Dekker associated syphilis with female bodies, especially in the context of dangerous religious beliefs, elsewhere, including in The Whore of Babylon (1605). 'The Empress of Babylon's "carbuncles and rich stones": 
The Metaphorizing of the Pox in Thomas Dekker's The Whore of Babylon', Early Theatre 7 (2004), 68, https://doi.org/10.12745/et.7.1.671.

12 Jean Howard discusses the trope of prostitutes' international clientele in London comedies as a kind of 'cosmopolitan perverse', an anxiety about the greater international contact in early modern England. Theater of a City: The Places of London Comedy, 1598-1642 (Philadelphia, 2007), 145.

13 Margaret Healy argues that the newly fervent Bellafront wants to convert her former clients and effectively marshals the otherwise misogynistic rhetoric in this scene. Fictions of Disease in Early Modern England: Bodies, Plagues, Politics (Basingstoke, 2001), 163, https://doi.org/10.1057/9780230510647.

14 Frankie Rubenstein catalogues the euphemisms for illness in the Boar's Head and elsewhere in Shakespeare. 'They Were Not Such Good Years', Shakespeare Quarterly 40.1 (1989), 72, https://doi.org/10.2307/2870754. All quotations from Shakespeare refer to The Complete Pelican Shakespeare, ed. Stephen Orgel and A.R. Braunmuller (New York, 2002).

15 Katharine Eisaman Maus, Inwardness and the Theater in the English Renaissance (Chicago, 1995), 160.

16 As Stephen Spiess observes, the scene traffics in euphemism, the right names 'conspicuously absent from their dialogue'. 'The Measure of Sexual Memory', Shakespeare Survey 67 (2014), 323, https://doi.org/10.1017/SSO9781107775572.022.

17 William Hamlin traces the evolution of critical responses to Freevill, from an older view of him as the comedy's 'moral center,' to one recognizing that he evolves over the course of the comedy and has only recently turned over a new leaf in his decision to abandon Franceschina and marry Beatrice. 'Common Customers in Marston's Dutch Courtesan and Florio's Montaigne', Studies in English Literature, 1500-1800 52.2 (2014), 411, https://doi.org/10.1353/sel.2012.0015.

18 Kate Aughterson argues that Freevill's permissiveness and embrace of virile masculinity mark him as a descendant of the Vice figure of morality plays. "Going the Way of All Flesh": Masculinity as Vice in The Dutch Courtesan', Cabiers Elisabéthains 76 (2009), 76, https://doi.org/10.7227/ce.76.1.4. Salkeld argues that Marston enhances the tension between the friends he found in Nicholas de Montreaulx, his source, arraying Malheureux and Freevill, at least at first, on opposite sides of the view of brothels' utility. Shakespeare among the Courtesans: Prostitution, Literature, and Drama, 1500-1650 (Farnham, 2012), 165, https://doi.org/10.4324/9781315608556.

19 Jonathan Gil Harris, Sick Economies: Drama, Mercantilism, and Disease in Shakespeare's England (Philadelphia, 2004), 49, 44. See Garrett A. Sullivan, Jr, “All Things Come into Commerce": Women, Household Labor, and the Spaces of Marston's The Dutch Courtesan', Renaissance Drama 27 (1996), 21, 
https://doi.org/10.1086/rd.27.41917326. On the role of commodity and the market in the period's comedies more generally, Douglas Brewster remains critical. Drama and the Market in the Age of Shakespeare (Cambridge, 1992), 41.

20 Hamlin argues that even as Freevill alludes to Montaigne in this speech, he misapplies the French essayist's view of custom. 'Common Customers', 414.

21 Steven Mullaney articulates the ambiguous space of London's liberties, the location of lazar houses, brothels, hospitals, and the theatres that enjoyed license in more ways than one and 'revealed the gaps and seams, the limits and contradictions of the social fabric'. The Place of the Stage: License, Play, and Power in Renaissance England (Chicago, 1988), 38. Revising this essay in March 2020, in the midst of a global pandemic, highlighted for me the difference between our modern notions of handling epidemics and the early modern mindset.

22 John Stow, Stow's Survey of London (London, 1956), 360.

23 Ibid, 361.

24 Ibid.

25 Ibid, 362. As Spiess notes, Stow memorializes an uncanny location. The brothels lost royal protection and were pulled down, creating something of a 'cartographic lacuna', for Stow's contemporary readers. 'Measure of Sexual Memory', 317.

26 Thomas Dekker, Lanthorne and Candle-light, in The Non-Dramatic Works of Thomas Dekker, ed. Alexander Grosart, 5 vols (rpt New York, 1963), 3.265.

27 Ibid, 3.276-7.

28 News from Gravesend, in The Plague Pamphlets of Thomas Dekker, ed. F.P. Wilson (Oxford, 1925), 101. Further references are to page numbers in this edition.

29 News from Gravesend, 102.

30 Ibid, 95, 99. Catherine Reedy argues that Middleton makes extensive use of the belief that a woman could suffer from the plague or the pox but not both simultaneously. "French Amulets", Expelling Poisons, and Contagion in The Changeling', Early Modern Literary Studies (forthcoming).

31 Girolamo Fracastoro, 'Syphilis, or the French Disease', in Latin Poetry, trans. James Gardner, (Cambridge, MA, 2013).

32 Gil Harris, Sick Economies, 44.

33 A Short and Profitable Treatise, B2r-v.

34 Nashe, Christs Teares over Iervsalem, in The Works of Thomas Nashe, ed. Ronald McKerrow, 5 vols (Oxford, 1958), 2.148.

35 Ibid.

36 'In Sickness and in Health: Medicine and Inter-Confessional Relations in Post-Reformation England', in Living with Religious Diversity in Early Modern Europe, ed. C. Scott Dixon, Dagmar Freist, and Mark Greengrass (Farnham, 2009), 180. 
37 Charles Parker argues that in Reformation polemic, Calvinists tended to associate Catholics with 'inordinate sensuality' while Catholics tended to link the bodies of their heretical Calvinist enemies with 'humoral contamination'. 'Diseased Bodies, Defiled Souls: Corporality and Religious Difference in the Reformation', Renaissance Quarterly 67.4 (2014), 1268, https://doi.org/10.1086/679783.

38 Nashe, Pierce Peniless his Supplication to the Diuell, in Works, ed. Ronald McKerrow, 5 vols (Oxford, 1958), 1.216. Further references are to McKerrow's edition. All references to Nashe in this paragraph are to page 216.

39 Kristen Poole explores the palimpsest of Falstaff superimposed onto his original, Sir John Oldcastle, a heroic puritan avant la lettre. Radical Religion from Shakespeare to Milton: Figures of Nonconformity in Early Modern England (Cambridge, 2006), 37.

40 Christopher W. Marsh offers the most sustained treatment of the sect in its English context. The Family of Love in English Society, 1550-1630 (Cambridge, 1994), 201.

41 [Lording Barry], The Family of Love, in Works of Thomas Middleton, ed. A.H. Bullen, 8 vols (Boston, 1885).

42 An Harmony of the Confessions of the Faith of the Christian and Reformed Churches (Cambridge, 1586; sTC: 5155), 469.

43 A Commentarie on the Fourth Booke of Moses (London, 1618; sтc: 893), 288.

44 An Arrow against the Separation of the Brownists (Amsterdam, 1618; sтc: 19098), 90.

45 Rev. 17:4, in The Geneva Bible, ed. Lloyd E. Berry (Madison, 1969). Further references are to this edition.

46 Adrian Streete argues that this seduction of an international clientele aligns Franceschina with the Whore of Babylon, who 'committed fornication [with] the Kings of the earth, and the inhabitants of the earth are drunken with the wine of her fornication' (Rev. 17:2). Apocalypse and Anti-Catholicism in Seventeenth-Century English Drama (Cambridge, 2017), 88, https://doi.org/10.1017/9781108235914.

47 The Epistle Exhortatorye ([Antwerp, 1544]; stc: 1291a), D6r. Bale also used the Whore of Babylon to characterize the Church of Rome in his history of the protoReformation martyr Sir John Oldcastle, the inspiration for Shakespeare's Falstaff.

48 The Mysterie of Iniquitie, trans. Samson Lennard (London, 1612; sTC: 18147), 544.

49 Scott shows the 'graphic quality, scale, and intensity of his dark rendering' of this nexus in Dekker's play. 'The Empress of Babylon's "carbuncles and rich stones”, 91.

50 Marsh argues that after a period of accommodation in the second half of Elizabeth's reign, the king's revision of his book of princely advice to his son on the occasion of his ascent to the English throne, explaining that by an earlier reference to puritans he intended members of the Family of Love, returned the sect to a place of critical examination, including in printed invective and in plays like Barry's and Marston's. The Family of Love in English Society, 201. 
51 A Confutation of Monstrous and Horrible Heresies, Taught by H.N. (London, 1579; sTC: 15040), ${ }^{*} 2$ r. Janet E. Halley offers a sophisticated reading of the slippery textuality of Elizabethan Familism, arguing that Familism and the established church create a sort of mutually constitutive understanding of each other. 'Heresy, Orthodoxy, and the Politics of Religious Discourse: The Case of the English Family of Love', Representations 15 (1986), 105-6, https://doi.org/10.2307/2928393. Christopher Carter suggests that the English divines who attacked the Dutch Familists dwelling in England did so in order to deflect the English hierarchy's attention from their own desire for further reformation. The Familists, associated with foreign prophets and tolerant even of the papacy (they were a spiritual movement, rather than a doctrine, after all), could be made scapegoats, 'a dangerous crypto-Catholic force within England'. 'The Family of Love and Its Enemies', Sixteenth Century Journal 37 (2006), 662-3, https://doi.org/10.2307/20477986.

52 In her new edition of the play, Britland traces the layers of Italian and French outlines that survive in Marston's use of his sources, even as he labels Franceschina a Dutch Familist. 'Introduction', The Dutch Courtesan, 22.

53 Sullivan addresses Mistress Mulligrub's sexual openness in his “'All Things Come into Commerce"', 32.

54 Ibid, 32. Leslie Thomson surveys the treatment of tradesmen's wives in the commercial context of London shops and London comedies, arguing that the playwrights' ambivalence undermines the 'fantasy' of the women as commercial commodities. "As proper a woman as any in Cheap": Women in Shops on the Early Modern Stage', Medieval and Renaissance Drama in England 16 (2003), 149.

55 Nashe, Christ's Tears over Jerusalem, 2.151.

56 Ibid. 
